\title{
Bypass Diodes for Improving Solar Panel Performance
}

\author{
Fadliondi, Haris Isyanto, Budiyanto
}

Department of Electrical Engineering, Universitas Muhammadiyah Jakarta, Indonesia

\begin{tabular}{|c|c|}
\hline Article Info & ABSTRACT \\
\hline Article history: & \multirow{5}{*}{$\begin{array}{l}\text { The ouput power of solar panel that decreased due to shading has been } \\
\text { improved using bypass diode method. The placement of bypass diodes } \\
\text { increased the output current and power. New peaks and maximum } \\
\text { powerpoints on the current-svoltage characteristics and power-voltage } \\
\text { characteristics were observed. Without bypass diodes, the maximum output } \\
\text { power was only around } 50 \mathrm{~W} \text {. After placing bypass diodes, the first peak } \\
\text { around } 115 \mathrm{~W} \text { and second peak around } 150 \mathrm{~W} \text { appeared at voltage of around } \\
31 \mathrm{~V} \text { and } 40 \mathrm{~V} \text {, respectively. }\end{array}$} \\
\hline Received Jul 14, 2017 & \\
\hline Revised Feb 13, 2018 & \\
\hline Accepted Aug 6, 2018 & \\
\hline Keyword: & \\
\hline \multicolumn{2}{|l|}{ Bypass } \\
\hline \multicolumn{2}{|l|}{ Diode } \\
\hline \multicolumn{2}{|l|}{ Improvement } \\
\hline \multicolumn{2}{|l|}{ Panel } \\
\hline Solar & $\begin{array}{r}\text { Copyright (c) } 2018 \text { Institute of Advanced Engineering and Science. } \\
\text { All rights reserved. }\end{array}$ \\
\hline \multicolumn{2}{|l|}{ Corresponding Author: } \\
\hline $\begin{array}{l}\text { Fadliondi, } \\
\text { Department of Electric } \\
\text { Universitas Muhammac } \\
\text { Jl. Cempaka Putih Teng } \\
\text { Email: fadliondi@ftum }\end{array}$ & Pusat 10510, Indonesia. \\
\hline
\end{tabular}

\section{INTRODUCTION}

The need for renewable energy keep increasing [1] by time because the world is running out fossil fuels which were formed millions years ago. If renewable sources are used, the fossil fuels will last longer. The main fossil fuels are oil, natural gas and coal. Oil has some disadvantages such as generating corbon dioxide, causing acid rain and being not clean. Natural gas also has some problems like creating greenhouse gas emmision, being volatile and being dangerous if carelessly transported. Like oil and natural gas, coal creates harmful waste, acid rain and health problem for the miners. The renewable energy is a solution to decrese dependence on fossil energy [2]. There are many sources of renewable energy such as wind, solar and hydroelectricity. Being noisy, being unpredictable and disturbing television and radio signals are three of disadvantages of wind power. Hydroelectricity also has some minuses like disrupting ecosystems, being costly and requiring expensive construction material. Compared to other sources of renewable energy, solar energy is very promising [3] because it is clean [4], cheap, abundant [5], silent [6] and having no pollution.

The solar energy is converted into electrical energy in order to be used in many appliances. A solar cell is an electronic device that use photovoltaic phenomenon to convert sunlight into electrical energy [7]. The smallest building block of solar cell that can generate electricity is called a p-n junction [8]. When packets of energy called photons hit the $\mathrm{p}-\mathrm{n}$ junction, atoms in, for example, $\mathrm{n}$ type region will absorb a photon, so an electron and a hole will be dislodged. After that, a free electron and free hole will be created. These free electrons and holes will later generate current. Mono crystalline, poly crystalline and thin film solar cells are common types of solar cells available in the world. The main material for mono crystalline and poly crystalline solar cells is silicon which is commonly used in the semiconductor industry. Meanwhile, gallium diselenide [9], amorphous silicon and cadmium telluride [10] are the common materials which are used to fabricate thin film solar cells. The higher efficiency compared to other type of aolar cells is the main advantage of mono crystalline solar cell. However, due to processes used to enhance the purity, mono 
crystalline solar cells are expensive compared to other types of solar cells. The highest efficiency of mono crystalline solar cells is around $17 \%-18 \%$ [11]. There are many factors that can degrade the performance of the solar cell like high temperature[12], excessive radiation[13], sand [14], dust covering the surface of the solar cell and shading. The aim of this work is to improve the performance of solar cells using bypass diodes and blocking diodes.

\section{RESEARCH METHOD}

Figure 1 shows the equivalent circuit of a solar cell. An perfect solar cell can be represented by a current source connected in parallel with a diode [15]. However, there is no ideal solar cell in real. In practice, a series resistance and a shunt resistance are added to this equivalent circuit. IL is the current generated by light coming into the cell. ID represents the current lost due to recombination. ISH is the current loss due to shunt resistance, RSH. The ideal value of the shunt resistance RSH and the series resistance RS are infinite and 0 , respectively [16]. If the shunt resistance is infinite, the ISH will be 0 which means that there is no current flowing.

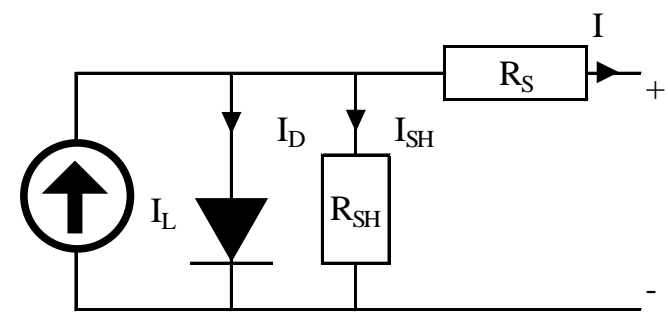

Figure 1. The equivalent circuit of a solar cell

Figure 2 illustrates how a solar cell and solar irradiance are measured. A solar cell will generate DC power when it is exposed to light A solar cell, a variable resistance box, two multimeters for voltage and current reading and wires are needed to measure I-V curve of the solar cell [17]. The choosing of resistors for solar cells measurement is very important. Small resistors like $1 / 2$ watt resistors can not be used to measure a solar panel because they will become overheated and burn out. It is very important to know the amount of sunlight hitting the surface of the solar cell. The most popular method that characterize solar radiation is the solar radiance Which is measured by a solarimeter [18]. The value of solar radiance ranges between $0 \mathrm{~W} / \mathrm{m}^{2}$ to about $1000 \mathrm{~W} / \mathrm{m}^{2}$. The local weather and location affect the solar radiance.

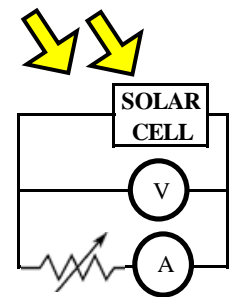

(a)

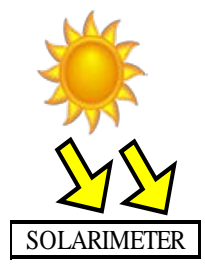

(b)

Figure 2. The measurement of (a) solar cell (b)solar irradiance

Figure 3 shows the schematic figure of bypass diodes and shading. The same current ideally will flow through the cells in a series array. If there is one cell shaded, it will result reverse bias which acts as a load and will cause some problems like hotspot which can damage the system [19]. There are two types of shading which are uniform and non-uniform [20]. 


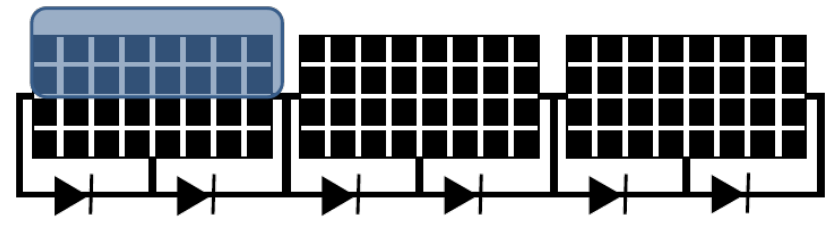

Figure 3. The shading and bypass diodes

\section{RESULTS AND ANALYSIS}

Figure 4 (a) shows panel I-V curve. This shows that as irradiance increased from $200 \mathrm{~W} / \mathrm{m}^{2}$ to 1000 $\mathrm{W} / \mathrm{m}^{2}$ at constant temperature of $25^{\circ} \mathrm{C}$, the output current also rose significantly while the voltage almost remained unchanged. For example, the panel current increased by $44 \%$ when the irradiance increased from $400 \mathrm{~W} / \mathrm{m}^{2}$ to $600 \mathrm{~W} / \mathrm{m}^{2}$. This means that the irradiance affects the output current much more strongly than the output voltage [21]. The short circuit current (ISC) proportionally increases with increasing radiation, but the change of open circuit voltage (VOC) is very small with increasing radiation [22]. Figure 4 (b) shows the $\mathrm{P}-\mathrm{V}$ curve of the solar panel. The curve indicates that the panel output power increased rapidly as the irradiance increased from $200 \mathrm{~W} / \mathrm{m}^{2}$ to $1000 \mathrm{~W} / \mathrm{m}^{2}$ at constant temperature. For example, the panel power increased by $60 \%$ when the irradiance increased from $400 \mathrm{~W} / \mathrm{m}^{2}$ to $600 \mathrm{~W} / \mathrm{m}^{2}$. However, the voltage almost remained constant.

The panel power depends on the amount of solar irradiance hitting the panel surface. Figure 5(a) ahows the I-V characteristics of PV panel measured under an irradiance of $980 \mathrm{~W} / \mathrm{m}^{2}$. From Figure 5(a), it can be seen that the ISC is closed to $4 \mathrm{~A}$ and the VOC is closed to $48 \mathrm{~V}$. The resulting P-V characteristics are shown in Figure 5(b). Figure 5 shows multiple steps in the I-V characteristics and multiple peaks in the P-V characteristics. If bypass diodes are connected, the unshaded cells will conduct the current. The shaded cells will limit the output current of the unshaded cells if the bypass diodes are not connected. Figure 6 shows the effect of partial shading on power output.

The horizontal axis represents time. The left and right vertical axes represent irradiance in $\mathrm{W} / \mathrm{m}^{2}$ and PV output in W respectively. Hourly solar radiation varied from 0 to $1000 \mathrm{~W} / \mathrm{m}^{2}$ and the average solar intensity was $426 \mathrm{~W} / \mathrm{m}^{2}$. Meanwhile, the hourly PV output range was from 0 to $150 \mathrm{~W}$ with average of $67 \mathrm{~W}$. Moreover, to increase the output power, methods like cooling and reflection from mirror can be used [23]. Recently, there is also research about organic semiconductor pentacene for solar cell [24]. Another important part of solar cell is absorber layer which convert light energy into voltage [25].

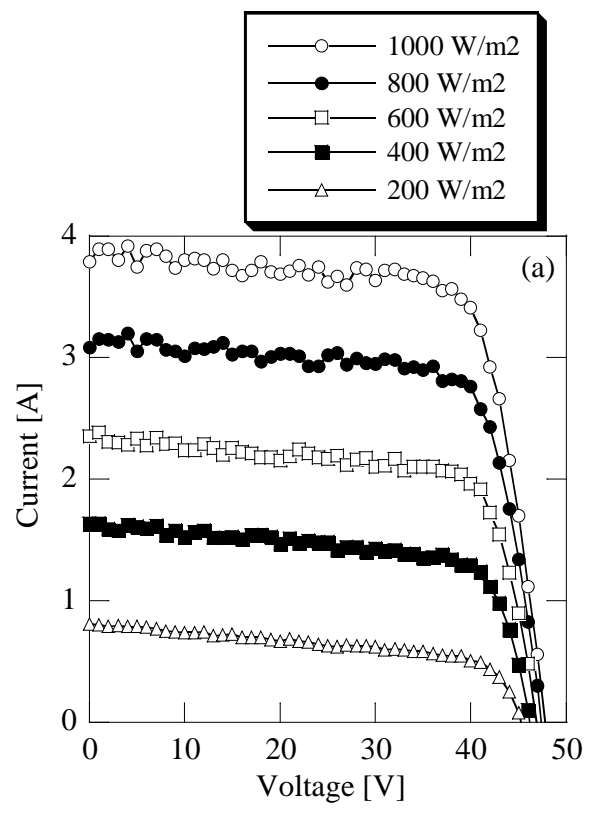

(a)

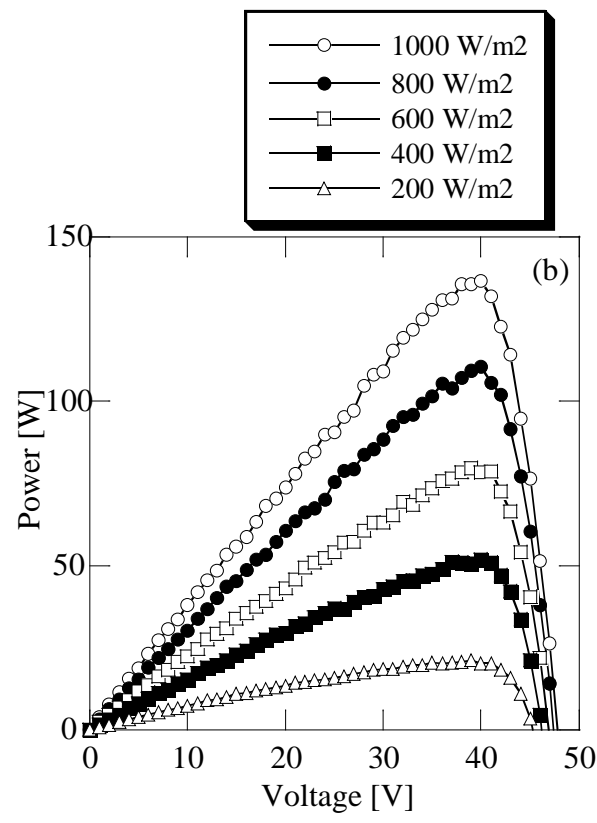

(b)

Figure 4. Irradiance dependence of (a) I-V curve, (b) P-V 


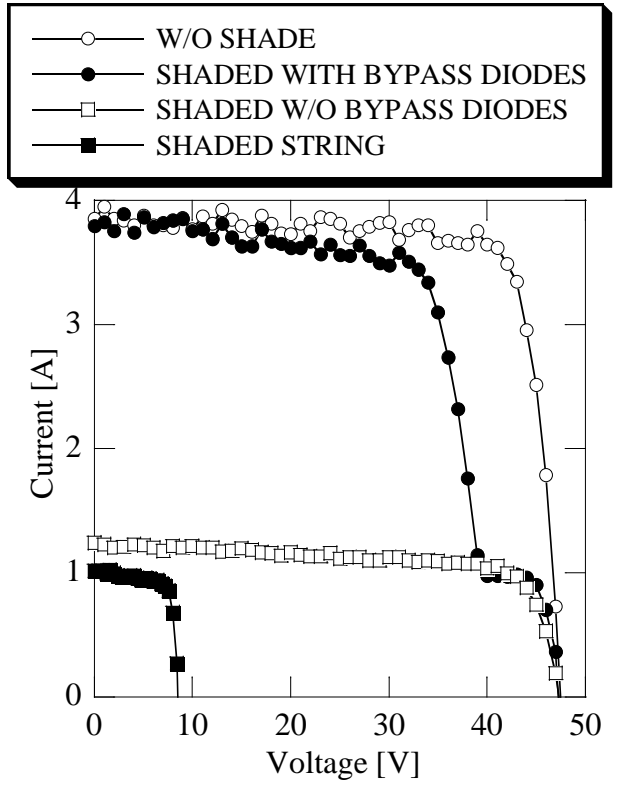

(a)

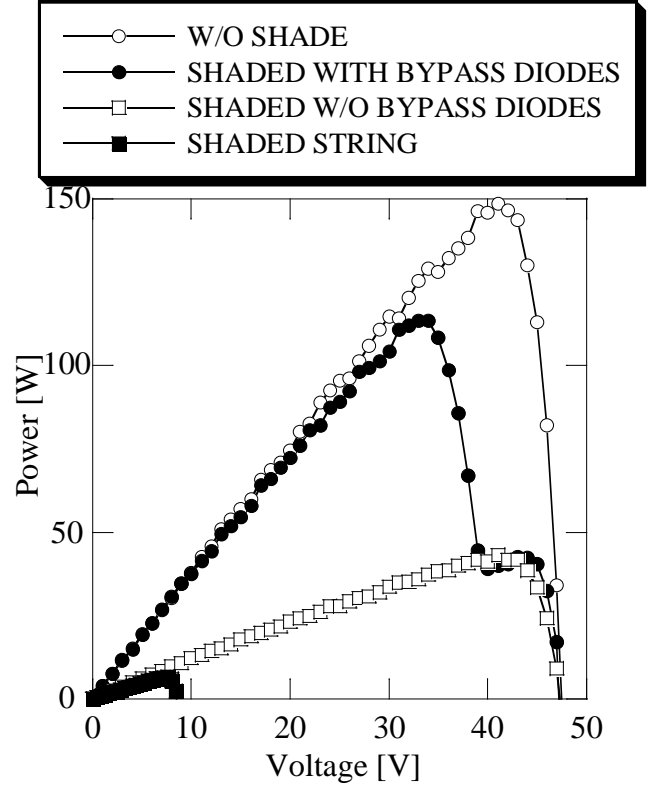

(b)

Figure 5. The effect of shading on (a) I-V curve (b) P-V curve

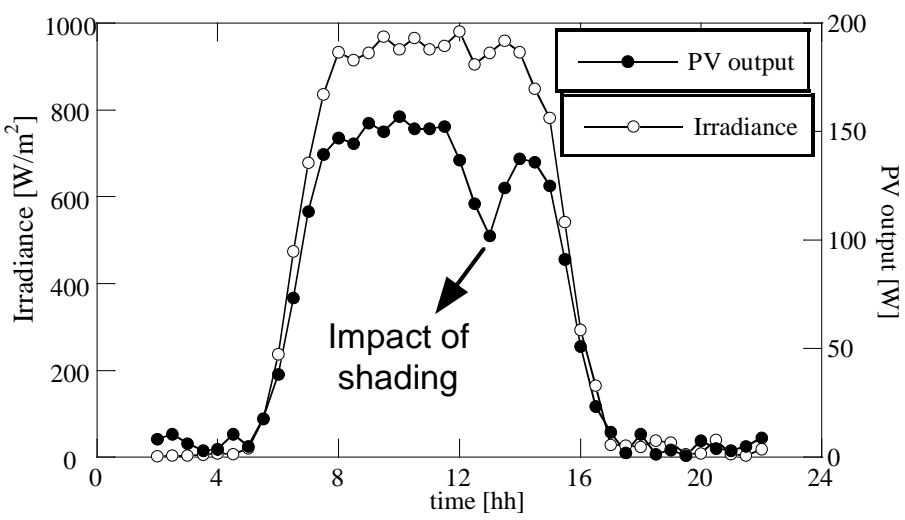

Figure 6. Impact of partial shading

\section{CONCLUSION}

The bypass diodes method has been applied to improve the output of solar panel that decreases due to shading. The shading over the PV panel, the placement of bypass diodes have a strong effect on the PV panel output power characteristics. By placing bypass diodes, the output current inceases and new peaks and maximum powerpoint appears.

\section{ACKNOWLEDGEMENTS}

Authors gratefully acknowledge the support of Fakultas Teknik Universitas Muhammadiyah Jakarta for their valuable suggestions and financial support. This paper is funded by Hibah Penelitian Internal PAKARTI Fakultas Teknik Universitas Muhammadiyah Jakarta nomor kontrak 77k/FTUMJ/V/2017.

\section{REFERENCES}

[1] N.L.Panwar, S.C.Kaushik, SurendraKothari, "Role of renewable energy sources in environmental protection: A review," Renewable and Sustainable Energy Reviews, vol. 15, pp. 1513-1524, 2011. 
[2] AyGegül TaGçJoLlu, Onur TaGkJn, and Ali Vardar, "A Power Case Study for Monocrystalline and Polycrystalline Solar Panels in Bursa City, Turkey," International Journal of Photoenergy, vol. 2016, pp. 1-7, 2016.

[3] Dharmendra thakur, Amit arnav, Abhishek datta, E.V.V Ramanamurthy, "A Review on Immersion System to increase the efficiency of Solar Panels," International Journal of Advanced Research, vol. 4, pp. 312-325, 2016.

[4] Michael D. Oisamoje, Esther Eguono Oisamoje, "Exploring the Economic and Environmental Benefits of Solar Energy Generation in Developing Countries: The Nigerian Perspective," Journal of Energy Technologies and Policy, vol. 3, pp. 23-30, 2013.

[5] Shahzada Adnan, Azmat Hayat Khan, Sajjad Haider, and Rashed Mahmood, "Solar energy potential in Pakistan," Journal of Renewable and Sustainable Energy, vol. 4, pp. -, 2012.

[6] Garo Pilawjian, "Analysis of Photovoltaic Concentrating Solar Energy Systems," ARPN Journal of Systems and Software, vol. 2, pp. 110-112, 2012.

[7] Tanvir Ahmad, Sharmin Sobhan, Md. Faysal Nayan, "Comparative Analysis between Single Diode and Double Diode Model of PV Cell: Concentrate Different Parameters Effect on Its Efficiency," Journal of Power and Energy Engineering, vol. 4, pp. 31-46, 2016.

[8] P.C.Choubey, A.Oudhia and R.Dewangan, "A review: Solar cell current scenario and future trends," Recent Research in Science and Technology, vol. 4, pp. 99-101, 2012.

[9] Jeyakumar Ramanujam, Udai P. Singh, "Copper indium gallium selenide based solar cells-a review," Energy \& Environmental Science, vol. 10, pp. 1306-1319, 2017.

[10] Ting L. Chu , Shirley S. Chu , "Recent progress in thin-film cadmium telluride solar cells," Progress in Photovoltaics, vol. 1, pp. 31-42, 1993.

[11] Shruti Sharma, Kamlesh Kumar Jain, Ashutosh Sharma, "Solar Cells: In Research and Applications—A Review," Materials Sciences and Applications, vol. 6, pp. 1145-1155, 2015.

[12] Furkan Dinçer, Mehmet Emin Meral, "Critical Factors that Affecting Efficiency of Solar Cells," Smart Grid and Renewable Energy, vol. 1, pp. 47-50, 2010.

[13] Nair Milind, Midhun Antony, Febin Francis, Jithu Francis, Joson Varghese, Sajith U K, "Enhancing the Efficiency of Solar Panel Using Cooling Systems," International Journal of Engineering Research and Applications, vol. 7, pp. 5-7, 2017.

[14] Ababacar Ndiaye, Cheikh M. F. Kébé, Pape A. Ndiaye, Abdérafi Charki, Abdessamad Kobi and Vincent Sambou, "Impact of dust on the photovoltaic (PV) modules characteristics after an exposition year in Sahelian environment: The case of Senegal," International Journal of Physical Sciences, vol. 8, pp. 1166-1173, 2013.

[15] M. Belarbi, A. Benyoucef, B. Benyoucef, "Study Of The Equivalent Circuit Of A Dyesensitized Solar Cells," Advanced Energy: An International Journal, vol. 1, pp. 1-8, 2014.

[16] Ravi Prakash, Sandeep Singh, "Designing and Modelling of Solar Photovoltaic Cell and Array," IOSR Journal of Electrical and Electronics Engineering, vol. 11, pp. 35-40, 2016.

[17] A. Ibrahim, "Analysis of Electrical Characteristics of Photovoltaic Single Crystal Silicon Solar Cells at Outdoor Measurements," Smart Grid and Renewable Energy, vol. 2, pp. 169-175, 2011.

[18] A.Lay-Ekuakille, G. Vendramin, A. Fedele, L. Vasanelli, A. Trotta, "PV Maximum Power Point Tracking Through Pyranometric Sensor:Modelling and Characterization," International Journal On Smart Sensing And Intelligent Systems, vol. 1, pp. 659-678, 2008.

[19] Amardeep Chaudhary, Shriya Gupta, Dhriti Pande, Fazal Mahfooz, Gunjan Varshney, "Effect of Partial Shading on Characteristics of PV panel using Simscape," International Journal of Engineering Research and Applications, vol. 5, pp. 85-89, 2015.

[20] Sathyanarayana P., Rajkiran Ballal, Lakshmi Sagar P. S., Girish Kumar, "Effect of Shading on the Performance of Solar PV Panel," Energy and Power, vol. 5, pp. 1-4, 2015.

[21] Mr. Dinesh S. Borkar, Dr.Sunil.V.Prayagi, Ms. Jayashree Gotmare, "Performance Evaluation of Photovoltaic Solar Panel Using Thermoelectric Cooling," International Journal of Engineering Research, vol. 3, pp. 536-539, 2014.

[22] M. Chegaar, A. Hamzaoui, A. Namoda, P. Petit, M. Aillerie, A. Herguth, "Effect of illumination intensity on solar cells parameters," Energy Procedia, vol. 36, pp. 722-729, 2013,

[23] Budiyanto, Fadliondi, "The Improvement of Solar Cell Output Power Using Cooling and Reflection from Mirror," International Journal of Power Electronics and Drive System, vol. 8, pp. 1320-1326, 2017.

[24] Fadliondi, "The Humidity Dependence of Pentacene Organic Metal-Oxide-Semiconductor Field-Effect Transistor," TELKOMNIKA, vol. 15, pp. 578-583, 2017.

[25] Sujarwata, Fianti, M.I. Amal, J.Y. Jung, S.H. Lee, K.H. Kim, "Critical Condition in CuInAlSe2 Solar Cell Absorbers,” TELKOMNIKA, vol. 14, pp. 867-872, 2016. 


\section{BIOGRAPHIES OF AUTHORS}

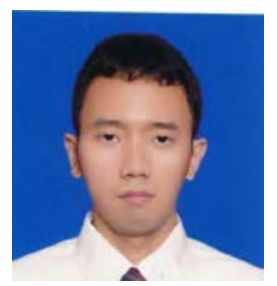

Fadliondi received his Master degree from Tokyo Institute of Technology. He is a lecturer at Universitas Muhammadiyah Jakarta. His research interests are electronics material and semiconductor devices.

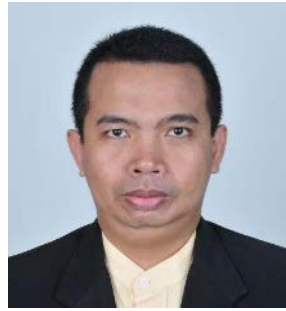

Haris Isyanto received his Master degree from Universitas Trisakti. He is a lecturer at Universitas Muhammadiyah Jakarta. His research interests are telecomunication and electrical engineering.

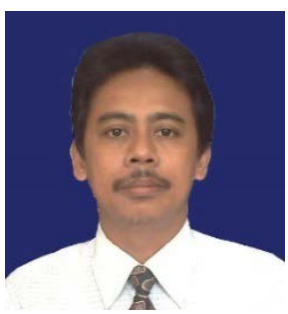

Budiyanto received his Doctoral degree from Universitas Indonesia. He is a lecturer at Universitas Muhammadiyah Jakarta. His research interests are power electronics, photovoltaic systems and renewable energy. 